\title{
PREVALENCE OF AEROMONAS HYDROPHILA IN OREOCHROMIS NILOTICUS FARMS IN KAFREL-SHEIKH GOVERNORATE
}

\author{
Y.R Azab And "G. I. Mazed \\ Bacteriology .provisional laboratory KafrEl-sheikh Governorate \\ "Bacteriology .provisional laboratory KafrEl-sheikh Governorate
}

\begin{abstract}
One hundred and Fifty six samples of Nile tilapia (Oreochromis niloticus), (53 samples from diseased and 103 samples from apparently healthy), were collected from different farms in different locality in Kafr Elsheikh Governorate,the samples were analysed for the prevalence of Aeromonas hydrophila over a period of nine months from first of December 2007 to end of Agusts 2008. and for their anti-microbial resistance using the disk diffusion method. Moreover the bacteria were tested for their pathogen city for fish and hemolytic activity,

The prevalence of Aeromonas hydrophila among Oreochromis niloticus were $6(35.3 \%)$. There was a clear seasonality, as one isolates (1.3\%) were recovered in the winter months while five isolates (6.4\%) recovered in summer.

Despite the high level of homogeneity observed in strains of Aeromonas hydrophila in biochemical patterns, they displayed different degrees of virulence for Tilapia fish; were $16.7 \%$ strong virulent, $50 \%$ virulent ,16.7\% weak virulent and $16.7 \%$ avirulent by subcutaneous injection of Aeromonas hydrophila isolates .

All strains of Aeromonas hydrophila showed hemolytic activity on blood agar except one avirulant strains showing non hemolytic activity. There is slight correlation was found between hemolytic activity and degree of virulence of the strains,also the isolates were tested against 13 antimicrobial agents and the result were, all the isolates were found 100\% resistant to Penicillin, Streptomycin, Polymyxin B,95\% for Ampicillin and $70 \%$ for Ciprofloxacin.All strains $100 \%$ sensitive to Amikacin, Gentamicin, Nalidixic acid, Kanamycin, Neomycin, Tetracycline, and 90\% Chloramphenicol.
\end{abstract}




\section{INTRODUCTION}

Aeromonas hydrophila, is a Gram-negative, rod shaped, mainly motile, facultative anaerobic, oxidase positive and glucose fermenting bacteria (Nordmann and Poirel, 2002). Some strains of Aeromonas hydrophila are capable of causing septicemia in fish and amphibians as well as extraintestinal and deep wound infections, gastroenteritis, cellulitis, meningitis, bacterimia, soft tissue infections, peritonitis, bronchopulmonary infections, and infection in humans with compromised immune systems (Ahmed 1983; Amin et al.,1985; Janda 1991; Chang et al., 1997). Furthermore, is frequently associated with disease in fresh water fish such as Tilapia (Ahmed 1983 and Amin et al.1985). In warm water aquaculture, Aeromonas hydrophila is considered to be a major economic problems, but it is difficult to distinguish direct losses from those caused by secondary infection (Ruangapan et al 1986 and Austin and Austin 1987). Aeromonds are common contaminants in a wide spectrum of foods namely fishes, raw and cooked meat, poultry, vegetables,milk and milk products (Agarwal et al.,2000; Bachhil et al.2002). These foods play an important role in the dissemination of the potentially pathogenic Aeromonas to humans.

Aeromonas hydrophila is able to survive and multiply at low temperatures in a variety of food products stored between -2 and $10 \mathrm{C}$ such as beef, roast beef and pork (Krovacek et al., 1992; Mano et al., 2000), and can produce virulence factors even at these low temperatures (Mateos $\boldsymbol{e t}$ al., 1993; Merino et al.,1995).

The pathogenicity of the organism is associated with the liberation of virulence factors and cell associated endotoxin. Virulence factors include the production of exotoxins (cytotoxin or enterotoxin) and $\alpha$ - Bhemolysins and ability to bind and to invade epithelial cells (Krovacek et al (1994). 
The main objective of this study was carried out to throw light on the following:

1- Prevalence of the Aeromonas hydrophila isolated from Oreochromis niloticus and seasonal occurance.

2- Correlation between the hemolytic activity and pathogenicity for fish of the isolated strains.

3- The resistance of isolated strains against different antibiotics.

\section{MATERIALS AND METHODS}

\subsection{Bacterial strains and growing conditions:}

Six strains of presumptive Aeromonas hydrophila were isolated from 156 ,Oreochromis niloticus collected from different farms in Kafr El-sheikh Governorate during a period of nine months from first of December 2007 to end of august 2008.Bacteria were isolated by inoculating plates of R-S agar (Shotts and Rimler1973) from fish skin, gills, liver, spleen and kidney then incubating the cultures at 28_C for $24 \mathrm{~h}$. Yellow colonies were then selected and identified to the genus Aeromonas. Suspected colonies were picked up and streaked onto the surface of Starch Ampicillin Agar (SAA), 5\% sheep blood agar, nutrient agar, and Tripticase Soy Agar (TSA) plates and Triple Sugar Iron (TSI) slant. All plates incubated at $28 \mathrm{C}$ for 24 hour. The isolated bacteria was identified by culture morphology, Gram-stain and biochemically according to (Popoff, 1984, Palumbo et. al., 1985, Glunder and Siegman, 1989 and Bisgaard et al., 1995). The colonies that showed typical reaction in TSI and positive for cytochrom oxidase test, oxidation and fermentation reaction of glucose and catalase test were confirmed as Aeromonas hydrophila. 


\section{2-2-Determination of hemolytic activity:}

Carried out according to Gerhardt et al.,(1981). The strains were tested for beta-hemolytic activity on Columbia agar base (Oxoid) supplemented with $5 \%$ sheep erythrocytes with incubation at $28^{\circ} \mathrm{C}$ for $48 \mathrm{~h}$. The presence of a clear colorless zone surrounding the colonies indicated B-hemolytic activity

\section{2-4-Pathogenicity assay:}

Carried out according to Kozin'ska et al.(2002). Nile tilapia fish of 30-35 gm/fish were obtained from El-Zawia fish farm at KafrEl -shiekh and free from disease, and transported to the laboratory in plastic buckets. The fish were maintained in 100-1 aquaria with aerated fresh water at $30+-2 \mathrm{C}$ for 2 weeks and fed commercial pellets in order to adapt to laboratory conditions. All fish were injected subcutaneously with $0.1 \mathrm{ml}$ of a suspension containing $600 \times 10^{6}$ bacterial cells in phosphate-buffered saline(PBS). Ten fish were injected per strain, and ten other fish, were injected with $0.2 \mathrm{ml}$ of sterile PBS as controls negative.The fish were then replaced into the aquaria and held under the same conditions as before injection. The morbidity and mortality of the fish were monitored daily for $7 \mathrm{~d}$ and the virulence level of the strains estimated and classified into four grouped as follows:- more than six fish with disease symptoms and mortality of five to 10 fish (strongly virulent); more than six fish with disease symptoms and mortality of one to four fish(virulent); more than four fish with disease symptoms and without mortality (weakly virulent) and one to four fish with slight pathological signs and without mortality or neither pathological signs nor mortality noted (avirulent).Recently dead fish and any survivors after 7 days were tested bacteriologically for the presence of injected bacterium in damaged fish tissues. 


\section{2-5- Antimicrobial susceptibility:}

\section{a- Culture Media:}

Mueller-Hinton agar (Oxoid): This medium was used for the disk diffusion test. It produces large and clear zone of inhibition when sensitive organisms are in contact with susceptible antibiotic.

\section{b-Antibiotic sensitivity disks: (Oxoid)}

The antibiotics and concentration ranges tested were showed as following table:

\begin{tabular}{||l||l||l||}
\hline Antimicrobial agent & Disc potency & \multicolumn{1}{||}{ Symbol } \\
\hline \hline Amikacin & $30 \mathrm{ug}$ & A \\
Nalidixic acid & $30 \mathrm{ug}$ & ND \\
Ampicillin & $10 \mathrm{ug}$ & Amp. \\
Ciprofloxacin & $5 \mathrm{ug}$ & \\
Chloramphenicol & $30 \mathrm{ug}$ & $\mathrm{C}$ \\
Streptomycin & $10 \mathrm{ug}$ & $\mathrm{S}$ \\
Gentamicin & $10 \mathrm{ug}$ & Gn \\
Kanamycin & $30 \mathrm{ug}$ & $\mathrm{K}$ \\
Neomycin & $30 \mathrm{ug}$ & N. \\
Penicillin & $10 \mathrm{ug}$ & P. \\
PolymyxinB & $300 \mathrm{U}$ & Pol.B \\
Tetracycline & $30 \mathrm{ug}$ & T. \\
Trimethoprim & $25 \mathrm{ug}$ & TXM \\
sulfamethoxazol & & \\
\hline \hline
\end{tabular}

\section{c- Methods:}

The resistance of all strains to different antimicrobial agents was determined by the disk diffusion method (Becton Dikinson, Microbiology Systems, MD, USA) according to FineGold and Martin (1982). The degree of sensitivity was determined and interpretation of their sensitivity were done according to Oxoid Manual (1982) and Koneman et al., (1983). 


\section{RESULTS}

Table (1): Prevalence of $\boldsymbol{A}$. hydrophila from apparently healthy and diseased Orechromas nilotucus.

\begin{tabular}{||c||c||c||c||c||}
\hline $\begin{array}{c}\text { Healthy } \\
\text { status }\end{array}$ & $\begin{array}{c}\text { Total of examined } \\
\text { samples }\end{array}$ & $\begin{array}{c}\text { Total bacterial } \\
\text { isolates }\end{array}$ & $\begin{array}{c}\text { Aeromonas } \\
\text { hydrophila }\end{array}$ & Other bacteria \\
\hline \hline Diseased & 53 & 9 & $4(44.4 \%)$ & $5(55.6 \%)$ \\
\hline $\begin{array}{l}\text { Apparently } \\
\text { healthy }\end{array}$ & 103 & 8 & $2(25 \%)$ & $6(75 \%)$ \\
\hline \hline Total & 156 & 17 & $6(35.3 \%)$ & $11(64.7 \%)$ \\
\hline
\end{tabular}

Table(2): rate of isolation of A.hydrophila from skin and internal organ of diseased and apparently healthy Tilapia fishs.

\begin{tabular}{|c||c|c||}
\hline \multirow{2}{*}{ Organ } & Diseased fish (4) & Apparently healthy fish ( 2) \\
\cline { 2 - 3 } & No (\%) & No (\%) \\
\hline \hline Skin & $2(50)$ & $1(50)$ \\
Gills & $1(33.3)$ & $0(0)$ \\
Spleen Heart & $0(0)$ & $1(50)$ \\
Kidney & $1(16.7)$ & $0(0)$ \\
Liver & $0(0)$ & $0(0)$ \\
& $0(0)$ & $0(0)$ \\
\hline \hline Total & $\mathbf{4 ( 1 0 0 )}$ & $\mathbf{2 ( 1 0 0 )}$ \\
\hline
\end{tabular}

Table (3): Incidence of A.hydrophila in relation to season.

\begin{tabular}{|c||c||c||}
\hline season & Total collected samples & No of isolated strains \\
\hline \hline Summer & 78 & $5(6.4 \%)$ \\
Winter & 78 & $1(1.3 \%)$ \\
\hline \hline Total & $\mathbf{1 5 6}$ & $\mathbf{6 ( 3 . 8 \% )}$ \\
\hline
\end{tabular}

Kafrelsheikh Vet. Med. J. Vol. 7 No. 1 (2009) 
Table (4): Correlation of degrees of virulence with hemolytic activity in six strains of $\boldsymbol{A}$. hydrophila.

\begin{tabular}{|c||c||c||c||}
\hline Isolate No & $\%$ & Degrees of virulence & Hemolytic activity On Sheep RBCs \\
\hline \hline 1 & $16.7 \%$ & Strong virulent & +++ \\
\hline 2 & $50 \%$ & Virulent & ++ \\
\hline 3 & & & ++ \\
\hline 4 & & & + \\
\hline 5 & $16.7 \%$ & Weak virulent & - \\
\hline 6 & $16.7 \%$ & A virulent & + \\
\hline
\end{tabular}

+ positive for haemolytic activity

- Negative for hemolytic activity

\section{Pathogenicity for fish:}

There was no death or sign of disease in fish injected with sterile PBS. (Table 3) presents the virulence level of six Aeromonas hydrophila strains tested in this study. Five strains were classified as strongly virulent, Virulent and weak virulent for fish. These strains caused motile aeromonad septicaemia with intensive external signs including hemorrhages, necrosis and ulcers. Between 10 and $80 \%$ of the fish died during the experiment, depending on the infection strain used. One strain were avirulant for fish and cause no mortality and signs of disease. There were differences in the pathogenicity among individual strains of Aeromonas.hydrophila. Strongly virulent, virulent, weak virulent and these avirulent strains differed in degree of haemolytic activity. 
Table (5): Antibiotic resistance of Aeromonas hydrophila isolates.

\begin{tabular}{||c||c|c||}
\hline \multirow{2}{*}{ Antibiotic } & \multicolumn{2}{|c|}{ Aeromonas.hydrophila } \\
\cline { 2 - 3 } & Resistance \% & Sensitivity \% \\
\hline \hline Ampicillin & 87.3 & 16.7 \\
Penicillin & 100 & 0 \\
ciprofloxacin & 66.7 & 33.3 \\
Amikacin & 0 & 100 \\
Streptomycin & 100 & 0 \\
Gentamicin & 0 & 100 \\
Nalidixic acid & 0 & 100 \\
Kanamycin & 0 & 100 \\
Neomycin & 0 & 100 \\
Tetracycline & 0 & 100 \\
Chloramphenicol & 16.7 & 83.3 \\
Polymyxin B & 100 & 0 \\
Trimethoprim- & 50 & 50 \\
sulfamethoxazol & 0 \\
\hline
\end{tabular}

The resistance patterns obtained with the 6 Aeromonas hydrophila strains against 13 antibiotics are shown in (Table 4). All strains showed $100 \%$ resistance to penicillin, Polymyxin B and Streptomycin In addition, the lowest resistances encountered were $83.3 \%$ to Ampicillin, $66.7 \%$ to Ciprofloxacin, while the rest were under $50 \%$. In contrast, all the strains were susceptible to Amikacin, Gentamicin, Nalidixic acid, Kanamycin, Neomycin and Tetracycline.

\section{DISCUSSION}

Biochemical identification of Aeromonas.hydrophila demonstrated that the prevalence of Aeromonas hydrophila among Oreochromis niloticus were $(35.3 \%)$, these result simulate the result obtained by Habib and Chowdhury (2001) who isolated A.hydrophila in percent 33.3\%. previous 
studies isolate Aeromonas hydrophila from Oreochromis niloticus with higher incidence 46\% (Bastawros and Amal 1999) and 94\% (Maria et al.2004). It has been suggested that the fish either harbours the pathogen at the time of capture or become infected during transport (Wiklund and Dalsgaard, 1998). With regard to the seasonal incidence of isolated A.hydrophila, 5(6.4\%) isolates were recovered during summer season, while only $1(1.3 \%)$ isolates were recovered during winter (Table 3$)$. In contrast Topic popovic et al.(2000) isolated A.hydroophila in winter and not isolated it in summer season Also our result lower than recorded by (Samia et al.,1996 and Cipriano et al.,2001) they isolated A.hydrophila with incidence $14(77.7 \%)$ during summer season and 4(22.2\%) during winter. The higher incidence in summer than winter in our country may be attributed to high temperature of water during summer which decreases oxygen solubility in water,so low oxygen content of water resulting in stress on fish and increase multiplication of A.hydrophila, which in turn make the fish susceptible to infection..

Hemolysin production is one of the properties associated with gastrointestinal infections caused by aeromonads. Results of this study show that the majority of the isolates were able to elaborate this virulence factor. In our study, 5 of the 6 (83.3\%) Aeromona hydrophila strains found in the present study were able to produce $\beta$-hemolytic activity. Previous studies reported 200 of the 240 (83.3\%) Aeromona hydrophila strains were able to produce $\beta$-hemolysis (Burke et al. 1983; Araujo et al. 1991; Asmat, and Gires, 2002). Other scientist found 57\% of the Aeromonas hydrophila showed hemolytic activity on agar plate (Chua Kek Heng,et al. 2005). From our result ,no higher activity was 
found in the less virulent strains (table 4) as reported by (Lallier et al. 1984). Others authors, mentioned that some association between Aeromonas hydrophila, phenotypic profile and specific disease signs was observed. (Kozin'ska et al.,2002).

In most pathology studies, motile aeromonads isolated from fish have been assigned to Aeromonas hydrophila (Santos et al. 1988; Del Corral et al. 1990; Kozin'ska 1996). Aeromonas hydrophila has been recovered from diseased fish (Huys et al. 1996). All Aeromonas strains (motile) were isolated from diseased fish and, after experimental infection, caused the disease in fish. Earlier reports indicated that Aeromonas hydrophila strains can be pathogenic for carp (Kozin'ska 1996) as well as for other fish species (Santos et al.1988; Toranzo et al. 1989). It is important in pathology studies to differentiate the pathogenic from the non-pathogenic strains. The results of our study showed that the hemolytic activity of some Aeromonas hydrophila differ in the of degree hemolysis, exept one strains has hemolytic activity and non pathogenic for fish (avirulant) (table 4).It was found in previous studies that pathogenic strains of motile aeromonads differ from non-pathogenic strains in their degree of hemolytic activity, (Leung et al. 1994; Kozin 'ska 1996; Sopin'ska et al. 1997).

Susceptibility Patterns of Aeromonas hydrophila to antimicrobial agents have varied,. In vitro susceptibility of the Aeromonas hydrophila isolates to a variety of antibiotics shown in (Table 5). Most strains were 100\% resistant to Penicillin, Streptomycin, Polymyxin B,95\%to Ampicillin, and $70 \%$ to Ciprofloxacin. The strains also showed $100 \%$ sensitivity to 
Amikacin, Gentamicin, Nalidixic acid, Kanamycin and Neomycin, our results are in contrast with data reported by other authors for clinical strains(Morita et al.,1994; Ko et al., 1996). found that strains of Aeromonas hydrophila isolated from different geographical areas were $100 \%$ susceptible to ampicillin, polymyxinB. Strains of Aeromonas hydrophia isolated from rivers (Gon i-Urriza et al., 2000) showed 59\% resistance against nalidixic acid while we encountered no resistance at all (0\%). In addition, these authors found $14 \%$ resistance to tetracycline and $1 \%$ to gentamicin against $0 \%$ for each them, in this work strains of Aeromonas hydrophila were $100 \%$ sensitivity to amikacin, ciprofloxacin, chloramphenicol, gentamicin, and kanamycin was found in a study that included a broad number of clinical and environmental strains (Mascher et al., 1988; Soliman 1988; Molero et al.,1989; Sohair and Eman 2002), in contrast to the resistance to ciprofloxacin found here. Also in a previous study analyzing 43 clinical strains of Aeromona hydrophila, and 100\% of them were susceptible to gentamicin and $100 \%$ of them to ciprofloxacin (Vila et al., 2002). Our results show that the drugs with the best antimicrobial effect against Aeromonas hydrophila, in agreement with data reported by other authors (Ko et al., 1996; Kämpfer et al.,1999; Vila et al., 2002). Therefore, these drugs could be the treatment of choice for extraintestinal infections, and also for patients with chronic diarrhoea caused by Aeromonas.

In conclusion, From the present study the hemolytic activity can differentiate between pathogenic and non pathogenic strains but is insufficient to determine their pathogen city for fish and the rate of infection with A.hydrophila in the summer higher than winter. 


\section{REFERENCES}

- Ahmed,S.M.(1983): Natural and expermintal studies on motil Aeromonas sepicaemia in fresh water fish (tilapia nilotica).M.V.Sc Thesis, Fac. Vet. Med.Assuit Univeristy.

- Agarwal, R. K., K.N.Kapoor, A.Kumar and K. N. Bhilegaonkar, (2000): Aeromonas in food of animal origin.Indian J. Anim. Sci., 70: 942-943.

- Amin, N.E., Abdallah, I.S., Elallawy, T.and ahmed, S.M.(1985): Motile Aeromonas septicaemia among Tilapia nilotica (Sarotherodon niloticus) in upper Egypt.J.fish pathol.,20:93-97

- Austin, B.and Austin,D.(1987):Bacterial fish pathogens. Publisher: Ellis Horwood limited, chichester,west Sussex,England.

- Araujo, R.M., Arribas, R.M. and Pares, R. (1991). Distribution of aeromonas species in waters with different levels of pollution. Journal of Applied Bacteriology. 71: 182-186.

- Asmat A. and Gires U. (2002). THE OCCURRENCE OF AEROLYSINPOSITIVE Aeromonas hydrophila STRAINS IN SEAWATER AND ASSOCIATED WITH MARINE COPEPODS Proceedings of the Regional Symposium on Environment and Natural Resources 10-11th. Vol 1: 495-502

- Bastawrows,A.F.and Amal,A.M.(1999). Some microbiological investigations in Aeromonas hydrophila group inOreochromis niloticus and Clarias lazera in Assiut Governorate .Assuit Vet. Med. J., 40 (80): pp.197-209. 
- Bachhil,V.N.,K.N.Bhilegaonka and R.K.Agarwal,(2002).Occurance of Aeromoas sp.In meatandmilk.Indian J.Comp. Microbial. Immunol. Infect.Dis.,23:81-82.

- Bisgaard,M.; Bianucci, F.and Sacchetti, R. (1995): Prevalence of Aeromonas spp. In surface waters Wal. Environ. Res.,67 (7), 10601064.

- Burke, V., Robinson, J., Beaman, J., Gracey, M., Lesmana, M., Rockhill, R., Echevarria, P. and Janda, J.M. (1983). Correlation of enterotoxicity with biotype in Aeromonas spp. Journal of Clinical Microbilogy. 18; 1196-1200.

- Chang, C.Y. Thompson, H., Rodman, N., Bylander, J. and Thomas, J. (1997). pathogenic analysis of Aeromonas hydrophila septicemia. Ann. Clin. Lab. Sci. 27: 254-259.

- Chua Kek Heng Son Radu,Salmah Ismail and Nuruliza Roslan (2005).Detection of haemolysin gene in Aeromonas isolated from Retailed fish in Malaysia .Journal of food Technology 3(2):108-112. ,

- Cipriano,R.C.;Bullock,G.L.and Pyle,S.W.(2001).Aeromonas hydrophila and motile aeromonad septiceias of fish.Revision of fish Disease Leaflet 68.U.s,Department of the interior fish and Wildlife Service. Division of fishery research, Washington.

- Del Corral, F., Shotts, E.B. Jr and Brown, J. (1990). Adherence, haemagglutination and cell surface characteristics of motile aeromonads virulent for fish. Journal of Fish Diseases 13, 255-268.

- Finegold,S.M. and Martin, W.J. (1982): Cited after Bailly and Scotts, Diagnosis Microbiology, $16^{\text {th }}$ Ed. Th C.V. Mosby Co.St. Louis Toronto London. 
- Gerhardt, P., Murray, R.G.E., Castilow, R.N., Nester, E.W., Wood, W.A., Krieg, N.R. and Phillips, G.B., (1981). Manual of Methods for General Bacteriology. American Society for Microbiology, Washington, DC.

- Glunder, G. and Siegmann, O. (1989). Occurrence of Aeromonas hydrophila in slid birds. Avian pathol. 18, 685-695.

- Gon i-Urriza, M., Pineau, L., Capdepuy, M., Roques, C., Caumette, P.and Quentin, C., (2000). Antimicrobial resistance of mesophilic Aeromonas spp. isolated from two European rivers. J. Antimicrob. Chemother. 46, 297-301.

- Habib, K.Z.and Chowdhury, M.B.(2001). Pathogenicity of Aeromonas Species isolated from Epizootic Ulcerative Syndrome (EUS) positive fish cultured in small scale farmers pond in Mymensingh.Bangladesh Veterinarian.18(1):pp.58-64.

- Huys, G., Coopman, R., Janssen, P. and Kersters, K. (1996). High resolution genotypic analysis of the genus Aeromonas by AFLP fingerprinting. International Journal of Systematic Bacteriology 46,

- Janda, J.M. (1991). Recent advances in the study of the taxonomy, pathogenicity and infectious syndromes associated with genus Aeromonas. Clin. Microbiol. Rev. 4. 397-410.

- Kämpfer,P.,Christmann,C.,Swings,J.and Huys, G., (1999). In vitro susceptibilities of Aeromonas genomic species to 69 antimicrobial agents. Syst. Appl. Microbiol. 22, 662- 669.

- Ko, W.C., Yu, K.W., Liu, CH.Y., Huang, CH.T., Leu, H.S. and Chuang,Y.CH., (1996). Increasing antibiotic resistance in clinical isolates of Aeromonas strains in Taiwan. Antimicrob. Agents Chemother. 40, 1260- 1262. 
- Koneman,E.W.Allen,S.D.; Dowell, V.R. and Sommers,H.M. (1983). Color Atlas and rextbook of diagnosticMicrobiology. $2^{\text {nd }}$ Ed.,1.B. Lippincott Company, NewYork, London..

- Kozin' ska, A. (1996). Wskaz'niki patogennos'ci Aeromonas hydrophila, Aeromonas caviae i Aeromonas sobria. Praca doktorska. Puławy: Pan'stwowy Instytut Weterynaryjny.

- Kozin'ska, A. Figueras2, M.J. Chacon, M.R. and Soler, L. (2002). Phenotypic characteristics and pathogenicity of Aeromonas genomospecies isolated from common carp (Cyprinus carpio L.) Journal of Applied Microbiology. 93, 1034-1041.

- Krovacek, K., Faris, A., Baloda, S.B., Peterz, M., Lindberg, T., and Mansson, I., (1992). Prevalence and characterization or Aeromonas spp. isolated from foods in Uppsala, Sweden. Food Microbiol.9, 29-36.

- Krovacek, K.; Pasquate, V.; Baloda, S. Sporano, V.; Conte, M. Dumontet, S. (1994). Comparison of putative virulence facyors in Aeromonas hydrophila strains isolated from the marine enviroment and human diarrhea cases in sothers Italy, Appl. Environ.Microbiol., 6o (4): 1379-1382

- Lallier, R; Bernard, F and Lalonde, G. (1984). Difference in the extracellular products of two strains of Aeromonas hydrophila virulent and weakly virulent for fish. Can J Microbiol. Jul;30(7):900-904.

- Leung, I.V., Yeep, I.V., Lam, T.I. and Sin, I.M. (1994). Serum resistance as a good indicator for virulence in Aeromonas hydrophila strains isolated from diseased fish in South-East Asia. Journal of Fish Diseases 18, 511-518.- 
- Mano,S.B., Ordoez, J.A., Garci'a de Fernando, G.D., (2000). Growth /survival of natural flora and Aeromonas hydrophila on. refrigerated uncooked pork and turkey packaged in modified atmospheres. Food Microbiol. 17, 657-669.

- Maria,J.; Sandra, N.and Paula, R.(2004).Resistance to B-Lactame antibiotics in Aeromnas hydrophila isolated from rainbow trout. International Microb.7(30):207-211.

- Mascher,E.F.; Reinther,F.F.Steinzner, D.and Lamberger,B.. (1988). Aermonas species in a municipal water supply of a center European City : Biotyping of strains and detection toxin. Zbi. Bakt. Hyg.b, 186: 333-337.

- Mateos, D., Anguita, J., Naharro, G. and Paniagua, C.,( 1993). Influence of growth temperature on the production of extracellular virulence factors and pathogenicity of environmental and human strains of Aeromonas hydrophila. J. Appl. Bacteriol. 74,111-118.

- Merino, S., Rubires, X., Knochel, S. and Toma's, J.M., (1995). Emerging pathogens: Aeromonas spp. Int. J. Food Microbiol. 28, $157-168$.

- Molero, X.; Bartolome, R.M.; Vinuesa,T. Guarner, L.Accarino, A.; Cassellas, F. and Garcia, R. (1989). Acute gastroenteritis due to vibrio parahaaemolyticus in Spain. Med. Clin. Bare.Jan, 14,92 (1) 1-4.

- Morita,K., Watanabe, N., Kurata, S., Kanamori, M., (1994). h-Lactam resistance of motile Aeromonas isolates from clinical and environmental sources. Antimicrob. Agents Chemother. 38,353-355. 
- Nordmann, P. and Poirel, L. (2002). Emerging carbapenemases in Gram-negative aerobes.Clinical Microbiology and Infection, 8: 321331.

- Oxoid Manual (1982). The Oxoid manual of culture media, ingredients and other laboratory services $5^{\text {th }}$ Ed. Oxoid Limit.

- Palumbo, A.S.; Marino,C.W.; Williams, A.C.; Buchanan, R.L.and Thraoer,D.W. (1985). Starch ampicillin agar for the quantitative detection of Aeromonas hydrophila. Appl. Environ. Microbiol, Oct. 50: 1027-1030.

- Popoff, M. (1984). Genus III Aeromonas. In Bergey's Manual of Determinative Bacteriology, Vol. 1. ed. Krieg, N.R. and Holt, J.G. pp.545-548. Baltimore, MD, USA: Williams \& Wilkins.

- Ruangapan, L.;Kitao,T.and Yoshida,T.(1986). protective efficacy of Aeromonas hydrphila vaccines in nile Tilapia. Vet. Imm .and Immuspath., 12:345-350.

- Samia, A.;Roufaydah,M.;Marzouk M.;Moustafa,M.and Gado, M. (1996). Studies on motile Aeromona septicemia in cultured carp in Egypt.Vet.Jour.of Giza.44(1):11-22

- Santos, Y., Toramnzo, A. E., Barja, j. L., Nieto, T. P. and Villa, G. (1988). Virulance properties and enterotoxin prodution of Aeromonas strains isolated from fish.Infection and Immunity 56,3285-3293.

- Shotts, E.B. Jr and Rimler, R. (1973). Medium for the isolation ofAeromonas hydrophila. Applied Microbiology 26, 550-553. 
- Sohair, Z.H. and Eman, k. E. A. (2002). Occurrence of Yersina enterocolitica and Aeromonas hydrophila in pasteurized milk in Sohag City.

- Soliman, K.M. (1988). The pathogenesis of Aeromonas hydrophila isolates in fish with special Emphasis on their control. Thesis Ph.D Fac. Vet. Med. Alex. Univ.

- Sopin'ska, A., Grochola, A. and Guz, L. (1997). Badanie zaleznos'ci pomie ‘dzy patogennos'cia , bakterii z rodzaju Aeromonas dla karpi a ich cytotoksycznos'cia . Medycyna Weterynaryjna 53, 394-397.

- Topic popovic N.E.,Teskeredzic, I.,Strunjak-perovic and R.CozRkovac.(2000).Aeromonas hydrophila isolated from freshwater fish in croatia.Vet Research Communication .24,371-377.

- Toranzo, A.E., Barja, A.M., Romalde, J.L. and Hetrick, F.M. (1989). Association of Aeromonas sobria with mortalities of adult gizzard shad, Dorosoma cepedianum Lesuer. Journal of Fish Diseases $12,439-448$.

- Vila, J., Marco, F., Soler, L., Chaco'n, M.R. and Figueras, M.J.,( 2002). In vitro antimicrobial susceptibility of clinical isolates of Aeromonas caviae, Aeromonas hydrophila and Aeromonas veronii biotype sobria. J. Antimicrob. Chemother. 49, 525- 529.

- Wiklund, T., Dalsgaard, I., (1998). Occurrence and significance of atypical Aeromonas salmonicida in non-salmonicid and salmonid fish species: a review. Dis. Aquat. Org. 32, 49-69. 


\section{مدى اتتشار ميكروب الايرومونس هيدروفيلا فى مزارع اسماك البلطى النيلي فى محافظة كفر الشيخ}

\section{ياسين رمضان عبل المولى عزب و جمال ابراهير مزيد}

تم تجميع 156عينة من اسماك البلطي النيلي (53من الأسماك المريضة '103من الأسماك السليمة ظاهريا ) من المز ارع المختلفة بمحافظة كفر الثيخ تم تحليل هذه العينات لمعرفة مدى انتشار ميكروب الايرومونس هيدروفيلا على مدي 9 شهور (موسم الثتاء و الصيف ) وذللك من بداية ديسمبر 2007 حتي نهاية أغسطس 2008 ومعرفة مدى مقاومة هذه المعزو لات للمضادات الحيوية وأيضا مدى ضر اوته لأسماك البلطي النيلي بالإضافة معرفة العلاقة بين درجه التحلل الدموي وضر اوة

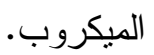

وقد أوضحت هذه الدراسة أن ميكروب الايرومونس هيدروفيلا ينتشر بنسبة 35.3\% قى اسماك البلطي النيلي في مزارع كفر الثيخ كما وجد أن نسبة انتشار ها فى موسم الثتاء 1(1.3\%) آم في موسم الصيف 5(6.4\%).

وعلى الرغم من التشابه الكبيرفى الاختبارات الكميائية لميكروب الايرومونس الا ان هنالك

اختلاف كبير في ضر اوة الميكروب حيث وجد ان هذة المعزو لات منها 16.71 \%، شديد الضراوة

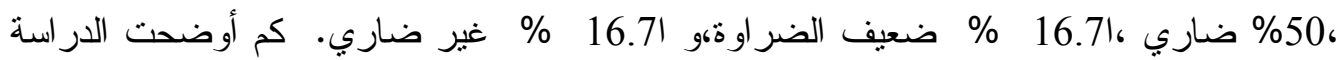
أن هذه المعزو لات له تأثثر على تحلل الدم ماعدا معزوله واحدة ليس لهل نأثثر على التحلل الدموي و غير ضارية .وتبين أن هناك علاقة بين ضر اوة الميكروب و التحلل الدموي على الأجار. كما اختبرت المعزو لات ضد 13 مضاد حيوي ووجد أن مقاومة الميكروب كانت بنسبة 100 \% للبنسلين، الاستر بتوميسين،البولى مكسين بي، 95\% للامبسيلين ،70\% للسيبروفلوكساسين وكانت جميع المعزو لات حساسة بنسبة 100\% اميكاسين، الجينتاميسين النالدكسك اسد و الكانا ميسين، النيوميسين ، التتر اسيكلين وبنسبة 90\% للكلورمفنيكول. 